\title{
Marfan syndrome - typical musculoskeletal abnormalities, rare occurrence in children
}

\author{
Zespót Marfana - typowe zaburzenia układu mięśniowo-szkieletowego, rzadko \\ występujące u dzieci
}

\author{
Zbigniew Żuber ${ }^{1}$, Anna Solakiewicz ${ }^{2}$, Dorota Turowska-Heydel ${ }^{1}$, Małgorzata Sobczyk ${ }^{1}$ \\ ${ }^{1}$ Department of Older Children with Subwards of Rheumatology, Neurology and Rehabilitation, St. Louis Children's Hospital, Krakow \\ ${ }^{2}$ Department of Children, Regional Hospital, Tarnow
}

Key words: Marfan syndrome, connective tissue disorders, mutation of fibrillin-1 gene, diagnosis.

Słowa kluczowe: zespół Marfana, choroby układowe tkanki łącznej, mutacja fibryliny-1, diagnostyka.

\begin{abstract}
Sum mary
Marfan syndrome (MFS) is an autosomal dominant connective tissue disorder. It is caused by a mutation in the fibrillin-1 (FBN1) gene located on chromosome 15 as a result of activation of transforming growth factor $\beta$. Since MFS affects most organs and tissues, patients with this disease constitute a clinically heterogeneous group. Specifically, MFS affects and causes disorders of the musculoskeletal system, eyes, heart and large blood vessels. A poor prognosis is expected due to the high risk of cardiovascular and ocular complications, which are caused by progressive dilatation of the aorta and ectopia lentis.

This article describes a case of MFS with typical musculoskeletal abnormalities.
\end{abstract}

\section{Introduction}

Marfan syndrome (MFS), first described in 1896 by Antoine-Bernard Marfan, is an autosomal dominant connective tissue disorder characterised by musculoskeletal, ocular and cardiovascular complications [1]. It is caused by a mutation in the fibrillin-1 (FBN1) gene on chromosome 15, which is responsible for modifications of the large glycoprotein fibrillin-1 - the main structural component of connective tissue microfibrils [1-3].

The prevalence of MFS is 2 per 10000 people [4]. So far, there have been identified about 1500 various mutations of

\section{Streszczenie}

Zespół Marfana (MFS) jest chorobą tkanki łącznej, genetycznie uwarunkowaną, dziedziczoną w sposób autosomalny dominujący. Przyczyną choroby jest mutacja w genie fibryliny 1 (FBN1) znajdującym się na chromosomie 15, w wyniku aktywowania transformującego czynnika wzrostu $\beta$. Ponieważ MFS dotyczy większości narządów i tkanek, pacjenci z tą chorobą stanowią niejednorodną grupę pod względem objawów klinicznych. W przebiegu MFS dochodzi do zmian i zaburzeń funkcji w obrębie układu mięśniowo-szkieletowego, narządu wzroku, serca i naczyń krwionośnych. Z uwagi na duże ryzyko wystąpienia powikłań sercowo-naczyniowych oraz ocznych, które są wynikiem stopniowego poszerzania aorty i ektopii soczewki, rokowanie w tej chorobie może być niepomyślne. W artykule przedstawiono przypadek zespołu Marfana z typowymi zaburzeniami układu mięśniowo-szkieletowego.

the FBN1 gene. Nevertheless, approximately one-fourth of MFS cases are caused by de-novo mutations. It has been demonstrated that fibrillin-1 microfibrils participate in the regulation of transforming growth factor $\beta$ (TGF- $\beta$ ) $[5,6]$. Normally, in a healthy individual TGF- $\beta$ is bound to connective tissue by fibrillin-1. In MFS, fibrillin-1 cannot bind to TGF- $\beta$ and cell signalling is deregulated $[6,7]$.

To make the clinical diagnosis of MFS, the revised Ghent nosology (Table I) which corresponds to the molecular analysis $[8,9]$ is used.

Here we present a case report of Marfan syndrome with typical musculoskeletal abnormalities [10, 11].

Address for correspondence:

Zbigniew Żuber, MD, PhD, Department of Older Children with Subwards of Rheumatology, Neurology and Rehabilitation, St. Louis Children's Hospital, Strzelecka 2, 31-503 Krakow, e-mail: zbyszekzuber@interia.pl

Submitted: 22.10.2014 
Table I. Ghent nosology (1996) [9]

\begin{tabular}{|c|c|c|}
\hline & Major criteria & Minor criteria \\
\hline Skeletal system & $\begin{array}{l}\text { At least four of the following: } \\
\text { - Pectus carinatum or pectus excavatum } \\
\text { - Arm span to height ratio }>1.05 \\
\text { - Positive wrist and thumb signs } \\
\text { - Scoliosis of }>20^{\circ} \\
\text { - Reduced elbow extension below } 170^{\circ} \\
\text { - Pes planus } \\
\text { - Protrusio acetabulae }\end{array}$ & $\begin{array}{l}\text { - Joint hypermobility } \\
\text { - Highly arched palate } \\
\text { - Characteristic facial appearance }\end{array}$ \\
\hline Cardiovascular system & $\begin{array}{l}\text { - Dilatation of the ascending aorta } \\
\text { - Dissection of the ascending aorta }\end{array}$ & $\begin{array}{l}\text { - Mitral valve prolapse } \\
\text { - Other dilatations of the aorta }\end{array}$ \\
\hline Ocular system & - Ectopia lentis & $\begin{array}{l}\text { - Myopia } \\
\text { - Others }\end{array}$ \\
\hline Pulmonary system & - & $\begin{array}{l}\text { - Spontaneous pneumothorax } \\
\text { - Apical blebs }\end{array}$ \\
\hline Skin & - & $\begin{array}{l}\text { - Striae atrophicae } \\
\text { - Recurrent or incisional herniae }\end{array}$ \\
\hline Nervous system & - Lumbosacral dural ectasia & - \\
\hline Genetic criteria & $\begin{array}{l}\text { - Family history } \\
\text { - Genetic mutations }\end{array}$ & - \\
\hline
\end{tabular}

\section{Case presentation}

A 5-year-old male patient reported to our department to undergo diagnostics in order to clarify the unexplained pain in the left femur that started three days earlier.

Medical history of the patient revealed a full term normal delivery, birth weight of 3800 grams and an Apgar score of 9 at the first minute. The pregnancy was uneventful. The mother previously had one miscarriage due to unknown reasons. The father had a normal body habitus $(52 \mathrm{~kg}, 170 \mathrm{~cm})$, and the mother $(50 \mathrm{~kg}, 163 \mathrm{~cm})$ was normal as well. There were no diagnosed cases of Marfan syndrome or incidences of sudden death in the immediate family.

On general examination, the patient was of tall stature, being over the $95^{\text {th }}$ percentile in height. Build of the patient was asthenic. The skin appeared dry with minimal subcutaneous fat. Muscle atrophy was observed, and muscle tension was reduced. The upper and lower limbs were characterized as being long and thin (dolichostenomelia). Moreover, extremities included long, slender hands and feet with spidery fingers (arachnodactyly). The ratio of the upper body segment (measured from the top of the head to the top of the symphysis pubis) to the lower body segment (measured from the top of the symphysis pubis to the sole) was $1: 1$, and the arm span exceeded the patient's total height. In addition, the anteroposterior diameter of the thoracic cage was reduced. What is more, there were present levoscoliosis of the thoracic spine, deep pectus excavatum and protruding scapulas. Other signs included abnormal joint flexibility of the upper and lower extremities (thumb flexibility sign, pinkie flexibility sign, fingers flexibility sign) and flat feet (pes planus). In addition, a special clinical test for evaluation of hyperextensibility of the thumb (Steinberg sign) and wrist (Walker sign) was positive.

Head and neck examination showed a convex profile with a long, narrow face, large ear lobes and small nostrils. An intraoral high arch palate was present. Temporomandibular joint (TMJ) open and closed views revealed hypermobility of the TMJ. Cardiac examination did not reveal presence of any murmurs over the heart. Lungs were clear. The abdomen was soft, and there were no signs of any inguinal hernias. Motor and psychological development was normal.

Results of laboratory tests were within normal values, except for elevated IgM class antibodies against Borrelia (both in ELISA and Western blot). Ultrasound examination of the hips and knees (performed twice) revealed no abnormalities.

Based on the clinical features of the patient, a diagnosis of MFS was made. The patient was then referred for ophthalmological and cardiac consultation. Ocular examination showed diminished visual acuity in both eyes and confirmed the presence of hyperopia and astigmatism. No signs of ectopia lentis or retinal ablation were found. Transthoracic cardiac evaluation with colour Doppler echocardiography revealed a small 
Table II. Major and minor criteria according to Ghent nosology fulfilled by the patient

\begin{tabular}{|ll|}
\hline \multirow{3}{*}{ Major criteria } & \multicolumn{1}{c|}{ Skeletal system } \\
\cline { 2 - 2 } & $\begin{array}{l}\text { deep pectus excavatum } \\
\text { arm span exceeds the patient's total }\end{array}$ \\
\cline { 2 - 2 } & $\begin{array}{l}\text { positive thumb (Steinberg) and wrist } \\
\text { (Walker) signs }\end{array}$ \\
\cline { 2 - 2 } & levoscoliosis of the thoracic spine \\
\cline { 2 - 2 } Minor criteria & $\begin{array}{l}\text { abnormal joint flexibility of the upper and } \\
\text { lower extremities }\end{array}$ \\
\cline { 2 - 2 } & $\begin{array}{l}\text { Highly arched palate with crowding of the } \\
\text { teeth }\end{array}$ \\
\cline { 2 - 3 } & $\begin{array}{l}\text { convex profile with a long, narrow face, } \\
\text { large ear lobes and small nostrils }\end{array}$ \\
\hline & Cardiovascular system \\
\hline Minor criteria & small dilatation of the aortic bulb \\
\hline Minor criteria & Ocular system \\
\hline & $\begin{array}{l}\text { diminished visual acuity in both eyes, } \\
\text { hyperopia and astigmatism }\end{array}$ \\
\hline
\end{tabular}

dilatation of the aortic bulb. Major and minor criteria according to Ghent nosology fulfilled by the patient are shown in Table II.

Finally, referral for genetic consultation was given.

\section{Discussion}

Marfan syndrome is an inherited degenerative connective tissue disorder with wide clinical variability which mainly affects the cardiovascular, ocular and skeletal systems [11-13].

Diagnosis of MFS in the youngest age group is difficult due to the high variability of the clinical picture of paediatric patients and significant variability of symptoms in developmental age. The described patient presented the most common symptoms in children aged below 10, similar to the data of French authors, who claim that the most common symptoms during the diagnosis are: high arch palate (82\%), arachnodactyly $(71 \%)$ and flat feet (59\%). In the analysed material, aortic aneurysm (47\%) and ectopic lens (35\%) were also observed in less than half of the patients under the age of 10 at the time of diagnosis [12].

Currently, the most cited nosology for the diagnosis of MFS is the revised Ghent criteria, which involve division into major and minor features in the ocular, skeletal, integumental, pulmonary and cardiovascular systems [9, 13-15].
According to the Ghent nosology, a diagnosis of MFS is made by finding a major criterion in at least two different organ systems and involvement of a third. For a family member, a major criterion in one organ system and involvement of a second is sufficient $[13,16]$.

The differential diagnosis of a tall, young person with Marfan-like skeletal features includes homocystinuria, Stickler syndrome, Ehlers-Danlos syndrome (EDS), Loeys-Dietz syndrome (LDS) and MASS phenotype (the acronym represents the following manifestations: a prolapsed mitral valve, myopia, aortic root enlargement, and skeletal and skin manifestations) $[6,12,17,18]$.

\section{Conclusion}

Marfan syndrome is a multisystem connective tissue disorder that affects the cardiovascular, ocular and skeletal systems. The inheritance of MFS is autosomal dominant, and the fibrillin-1 gene mutation plays a dominant negative role. To make the diagnosis of MFS, the revised Ghent nosology is used [9].

Since the clinical diagnosis using the Ghent nosology corresponds to the molecular analysis, specific genetic tests (which are difficult of access and expensive) are not necessary in patients who fulfil the diagnostic criteria for MFS $[13,16]$.

Early detection of MFS greatly facilitates comprehensive care for the patient and allows for early, effective intervention in the case of typical organ damage $[8,12,16]$.

The authors declare no conflict of interests.

\section{References}

1. Lipscomb KJ, Clayton-Smith J, Harris R. Evolving phenotype of Marfan's syndrome. Arch Dis Child 1997; 76: 41-46.

2. Staufenbiel I, Hauschild Ch, Kahl-Nieke B, et al. Periodontal conditions in patients with Marfan syndrome - a multicenter case control study. BMC Oral Health 2013; 13: 59.

3. Zimmermann-Górska I. Nadmierna ruchomość stawów a choroby reumatyczne. Reumatologia 2007; 45: 397-403.

4. Chiu HH, Wu MH, Chen HC. Epidemiological profile of Marfan syndrome in a general population: a national database study. Mayo Clin Proc 2014; 89: 34-42.

5. Wypasek E, Potaczek DP, Stąpor R, et al. First report of the genetic background of Marfan syndrome in Polish patients. Pol Arch Med Wewn 2013; 123: 646-647.

6. Hoffjan S. Genetic Dissection of Marfan Syndrome and Related Connective Tissue Disorders: An Update 2012. Molecular Syndromology 2012; 3: 47-58.

7. Benke K, Ágg B, Szilveszter B, et al. The role of transforming growth factor-beta in Marfan syndrome. Cardiol J 2013; 20 : 227-234.

8. Szydłowski L, Pucicka-Hoffmann K, Smoleńska-Petelenz J, Krzystolik-tadzińska J. Clinical investigation and echocardiogra- 
phy value in accuracy of Marfan's syndrome diagnosis. Pediatr Med Rodz 2009; 5: 264-270.

9. DePaepe A, Deitz HC, Devereux RB, et al. Revised diagnostic criteria for the Marfan syndrome. Am J Med Genet 1996; 62: 417-426

10. Gray JR, Davies SJ. Marfan syndrome. J Med Genet 1996; 33: 403-408.

11. Kaissi Al A, Zwettler E, Ganger R, et al. Musculo-skeletal abnormalities in patients with Marfan syndrome. Clin Med Insights Arthritis Musculoskelet Disord 2013; 6: 1-9.

12. Laffargue F, Lienhardt-Roussie A, Lacombe D, Delrue MA. Clinical signs of Marfan syndrome in children under 10 years of age. Arch Pediatr 2013; 20: 1193-1200.

13. Dean J. Marfan syndrome: clinical diagnosis and management. Eur J Hum Genet 2007; 15: 724-733.

14. Lopez R, Berg-McGraw J. Marfan syndrome in a female collegiate basketball player: a case report. J Athl Train 2000; 35 91-95.

15. Datta S, Datta H. Subluxation of lens in Marfan syndrome. Indian Pediatr 2009; 46: 434.

16. Raanani E, Ghosh P. The multidisciplinary approach to the Marfan patient. Ir Med Assoc J 2008; 10: 171-174.

17. Shi-Min Yuan, Hua Jing. Marfan's syndrome: an overview. Sao Paulo Med J 2010: 128: 360-366.

18. Bergman R, Nevet MJ, Gescheidt-Shoshany H. Atrophic skin patches with abnormal elastic fibers as a presenting sign of the MASS phenotype associated with mutation in the fibrillin 1 gene. JAMA Dermatol 2014; 150: 885-889. 